\title{
The Mizoroki-Heck reaction in organic and aqueous solvents promoted by a polymer-supported Kaiser oxime-derived palladacycle
}

\author{
Emilio Alacid and Carmen Nájera* \\ Departamento de Química Orgánica and Instituto de Síntesis Orgánica (ISO), \\ Universidad de Alicante, Apartado 99, 03080 Alicante, Spain \\ E-mail: cnajera@ua.es
}

Dedicated to Professor Arlette Solladié-Cavallo on occasion of her 70th birthday

\begin{abstract}
A polystyrene-supported palladacycle derived from Kaiser oxime resin $\mathbf{3}$ is examined in organic and aqueous media used for the Mizoroki-Heck reactions. The couplings are efficiently performed in the presence of polymeric palladacycles in DMF, aqueous DMA, or water at relatively moderate temperature $\left(110-130^{\circ} \mathrm{C}\right)$ similarly to that in the presence of dimeric 4hydroxyacetophenone $\mathbf{6}$ and 4-nitrobenzophenone oxime 2 palladacycles. Different acrylic, crotonic, and cinnamic acid derivatives as well as styrenes are arylated with aryl iodides, bromides, and chlorides with high efficiency. Enone precursors of 4-( $p$-hydroxyphenyl) and 4( $p$-methoxy)phenylbutan-2-one, which are natural odorous products extracted from Aloe wood with raspberry scent, have been prepared by arylation of methyl vinyl ketone. Methylated resveratrol and the anti-cancer agent DMU-212 [(E)-3,4,5,4'-tetramethoxystilbene] have been prepared in high yields. Related Mizoroki-Heck reactions of $o$-halobenzaldehydes and $o$ iodoaniline with tolane afforded indenone and indol derivatives, respectively. XPS analysis of the starting and recycled polymer indicated that contains exclusively $\mathrm{Pd}(\mathrm{II})$. In addition, poisoning studies with $\mathrm{Hg}(0)$ of the reaction mixture stop the process indicating that the palladacycle acts as source of $\operatorname{Pd}(0)$ species. Recycling experiments are performed in organic and aqueous solvents with relatively low palladium leaching from the polymer $(0.4-5 \%$ in DMF and $2-2.7 \%$ in $\mathrm{H}_{2} \mathrm{O}$ ). ICP-OES analyses also indicate very low levels of $\mathrm{Pd}$ in the isolated crude products (2.9-37.2 $\mathrm{ppm})$.
\end{abstract}

Keywords: Palladacycles, polystyrene, oximes, alkenes, Heck reaction 


\section{Introduction}

Among palladium catalyzed reactions, the arylation of alkenes so-called Mizoroki-Heck reaction, ${ }^{1,2}$ is one of the most important carbon-carbon bond forming processes. Along the last 25 years an impressive number of applications have been developed at the laboratory and industrial scale. Most of publications deals with the synthesis of complex molecules and also with practical aspects such as, reaction conditions, palladium catalysts, substrates, recycling experiments and mechanistic considerations. Different types of ligands for Pd have been developed in order to afford high efficiency with unreactive substrates such as aryl chlorides, and to achieve high TON and TOF values. Palladacycles have become an important class of complexes due to their accessibility, stability, and high catalytic activity in different type of carbon-carbon bond forming reactions. ${ }^{3}$ It has been demonstrated that palladacycles are precatalyst acting as source of Pd nanoparticles, ${ }^{4}$ and therefore working as homogeneous ligand-free palladium catalysts. ${ }^{5}$ Palladacycles are not stable under Mizoroki-Heck reaction conditions and undergo decomposition, probably by olefin insertion into the C-Pd bond and subsequent $\mathrm{Pd}(\mathrm{II})$ to $\operatorname{Pd}(0)$ reduction. ${ }^{6}$ However, using a polymer supported palladacycle it has been found that the catalytic activity can be maintained in the solution. ${ }^{7}$

Phenone oxime-derived palladacycles ${ }^{8}$ have shown an outstanding catalytic activity of $10^{10}$ turnover numbers (TON), close to enzymatic values, in the arylation of n-butyl acrylate with phenyl iodide in DMF and with $\mathrm{Et}_{3} \mathrm{~N}$ as base at $160{ }^{\circ} \mathrm{C}$. ${ }^{9}$ This behaviour has been explained by an equilibrium between $\mathrm{Pd}$ aggregates and monomeric species when the concentration of palladacycle decreases. ${ }^{10}$ 4,4'-Dichlorobenzophenone $\mathbf{1}$ and 4-hydroxyacetophenone oxime 2 palladacycles ${ }^{11}$ have been used as precatalyst in different type of $\mathrm{C}-\mathrm{C}$ bond forming reactions under aerobic conditions in organic and aqueous solvents, respectively., ${ }^{8,9,12} \mathrm{We}$ have recently communicated the preparation and catalytic activity of the palladated Kaiser oxime resin $\mathbf{3}$ as precatalyst in Mizoroki-Heck reactions. ${ }^{13}$ Although the known decomposition of palladacycles into Pd colloids, it would be important from a practical point of view to study the scope of this polymer 3 as precatalyst and at the same time its recovery. In this paper, we report a full account about the use of this polystyrene supported complex as precatalyst in the arylation of electronpoor and electron-rich alkenes in organic and aqueous solvents.

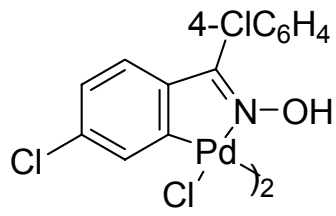

1

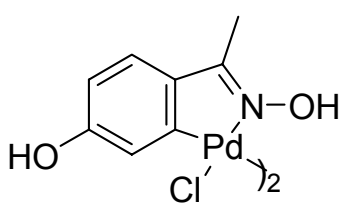

2

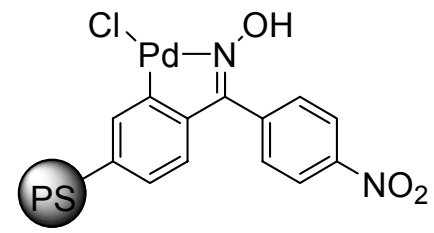

3 


\section{Results and Discussion}

Catalyst 3 was prepared according to the reported method, ${ }^{12 \mathrm{k}}$ starting from commercially available Kaiser oxime resin 4 (1\% divinylbenzene cross-linked with $1.1 \mathrm{mmol} \mathrm{g}^{-1}$ oxime loading), which was palladated by treatment with a $0.5 \mathrm{M}$ methanolic solution of $\mathrm{Li}_{2} \mathrm{PdCl}_{4}$ in the presence of $\mathrm{NaOAc}$ at room temperature for 1 week. The Pd content $\left(0.12 \mathrm{mmol} \mathrm{g}^{-1}\right)$ of the new polymer 3 was determined by ICP-OES. In order to find out where the $\mathrm{Pd}$ is bonded a dimeric complex 6 was prepared by palladation of 4-nitrobenzophenone oxime 5 in 94\% yield. This palladacycle 6 was reduced with $\mathrm{NaBD}_{3} \mathrm{CN}$ to the corresponding deuterated oxime $\mathbf{5}$ in $91 \%$ yield, indicating that the palladation took place at the unsubstituted phenyl group (Scheme 1). Comparing the FT-IR spectra of the polymer 3 and complex $\mathbf{6}$ it was be deduced that both have a similar structure. ${ }^{12 \mathrm{k}}$

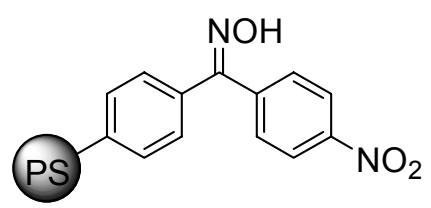

4<smiles>O=[N+]([O-])c1ccc(/C(=N\O)c2ccccc2)cc1</smiles>

5

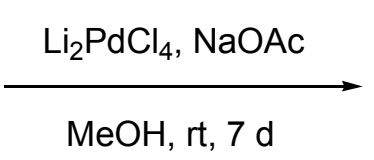

$\mathrm{Li}_{2} \mathrm{PdCl}_{4}, \mathrm{NaOAc}$

$\mathrm{MeOH}, \mathrm{rt}, 3 \mathrm{~d}$

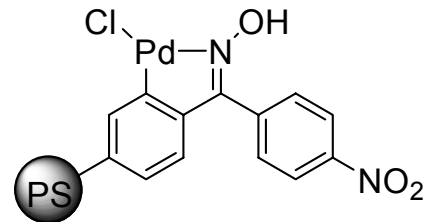

3

6

Scheme 1. Synthesis of palladacycles 3 and 6.

The arylation of methyl or tert-butyl acrylates and styrene in organic solvents with different aryl halides was carried out using the different palladacycles $\mathbf{2}, \mathbf{3}$, and $\mathbf{6}$ using tertiary amines (Table 1). Initial studies were performed at the moderate temperature of $110^{\circ} \mathrm{C}$ in order to avoid thermal decomposition of polymeric complex 3. Quantitative yields were obtained in the arylation of methyl acrylate with iodobenzene in $\mathrm{DMF}$ and $\mathrm{Et}_{3} \mathrm{~N}$ as base using palladacycles $\mathbf{1 , 3}$, and 6, polymer complex 3 being less efficient (Table 1, entries 1-3). In the case of styrene, palladacycle 1 and 3 gave similar results (Table 1, entries 4 and 5). However, the use of $\mathrm{Cy}_{2} \mathrm{NMe}$ instead of $\mathrm{Et}_{3} \mathrm{~N}$ afforded similar results in shorter reaction times (Table 1, compare entries 5 and 6). In addition, polymeric and dimeric complexes 3 and $\mathbf{6}$ gave similar results (Table 1, entries 6 and 7). When 4-chlorophenyl bromide was used for the arylation of tert-butyl acrylate in $N, N$ dimethylacetamide (DMA) instead of DMF as organic solvent, the addition of tetra- $n$ butylammonium bromide (TBAB) allowed to give high yields with a low loading $(0.01 \mathrm{~mol} \%$ of 
Pd) of precatalysts 2, 3, and 6 (Table 1, entries 8-10). Similar results were obtained for the arylation of styrene (Table 1, entries 11-13). 4-Nitrophenyl chloride was chosen as an activated aryl chloride for the coupling with tert-butyl acrylate and styrene at $120^{\circ} \mathrm{C}$ with 1 and $0.5 \mathrm{~mol} \%$ of Pd loading of complex 3 and 6, respectively (Table 1, entries 14-17). These reactions were also performed in the presence of TBAB as additive, affording the corresponding tert-butyl $p$ nitrocinnamate and 1-phenyl-2(p-nitrophenyl)ethylene, respectively, in good yields with both palladacycles.

Table 1. Mizoroki-Heck reactions in organic solvents. Reaction conditions ${ }^{\mathrm{a}}$

\begin{tabular}{|c|c|c|c|c|c|c|c|c|}
\hline Entry & ArX & Alkene & $\begin{array}{c}\text { Cat. } \\
(\mathrm{Pd}, \\
\mathrm{mol} \%)\end{array}$ & Base & Solvent & $\mathrm{t}(\mathrm{h})$ & Product & $\begin{array}{l}\text { Yield } \\
(\%)^{b}\end{array}$ \\
\hline 1 & $\mathrm{PhI}$ & $\mathrm{CH}_{2}=\mathrm{CHCO}_{2} \mathrm{Me}$ & $\mathbf{1}(0.1)$ & $\mathrm{Et}_{3} \mathrm{~N}$ & DMF & 1.2 & $\mathrm{Ph} \rightleftharpoons$ & $99^{\mathrm{c}}$ \\
\hline 2 & & & $\mathbf{3}(0.1)$ & & & 1.6 & & $97(92)$ \\
\hline 3 & & & $\mathbf{6}(0.1)$ & & & 0.75 & & 99 \\
\hline 4 & $\mathrm{PhI}$ & $\mathrm{CH}_{2}=\mathrm{CHPh}$ & $\mathbf{1}(0.1)$ & $\mathrm{Et}_{3} \mathrm{~N}$ & & 4 & & $98^{\mathrm{c}, \mathrm{d}}$ \\
\hline 5 & & & $\mathbf{3}(0.1)$ & & & 6 & & $94^{\mathrm{e}}$ \\
\hline 6 & & & $\mathbf{3}(0.1)$ & $\mathrm{Cy}_{2} \mathrm{NMe}$ & & 3.5 & & $98^{\mathrm{f}}$ \\
\hline 7 & & & $\mathbf{6}(0.1)$ & & & 3.2 & & $96^{\mathrm{d}}$ \\
\hline 8 & $\begin{array}{c}\text { 4-Cl- } \\
\mathrm{C}_{6} \mathrm{H}_{4} \mathrm{Br}\end{array}$ & $\mathrm{CH}_{2}=\mathrm{CHCO}_{2} \mathrm{Bu}^{t}$ & $2(0.01)$ & $\mathrm{Cy}_{2} \mathrm{NMe}$ & DMA $^{g}$ & 14 & $4-\mathrm{ClC}_{6} \mathrm{H}_{4}$ & 99 \\
\hline 9 & & & $3(0.01)$ & & & 14 & & $96(84)$ \\
\hline 10 & & & $\mathbf{6}(0.01)$ & & & 14 & & $99(88)$ \\
\hline 11 & & $\mathrm{CH}_{2}=\mathrm{CHPh}$ & $2(0.01)$ & & & 14 & $\mathrm{CIC}_{6}$ & $98^{\mathrm{h}}$ \\
\hline 12 & & & $\mathbf{3}(0.01)$ & & & 24 & & $92^{\mathrm{i}}$ \\
\hline 13 & & & $\mathbf{6}(0.01)$ & & & 14 & & $99^{j}$ \\
\hline 14 & $\begin{array}{l}4-\mathrm{NO}_{2}- \\
\mathrm{C}_{6} \mathrm{H}_{4} \mathrm{Cl}\end{array}$ & $\mathrm{CH}_{2}=\mathrm{CHCO}_{2} \mathrm{Bu}^{t}$ & $3(1)$ & $\mathrm{Cy}_{2} \mathrm{NMe}$ & $\mathrm{DMA}^{\mathrm{g}, \mathrm{k}}$ & 14 & $4-\mathrm{NO}_{2} \mathrm{C}_{6} \mathrm{H}$ & $99(96)$ \\
\hline 15 & & & $6(0.5)$ & & & 14 & & 92 \\
\hline 16 & & $\mathrm{CH}_{2}=\mathrm{CHPh}$ & $3(1)$ & & & 10 & $4-\mathrm{NO}_{2} \mathrm{C}_{6} \mathrm{H}$ & $86^{\mathrm{i}}(69)$ \\
\hline 17 & & & $6(0.5)$ & & & 7 & & $93^{1}$ \\
\hline
\end{tabular}

${ }^{\text {a }}$ The reactions were carried out using $1 \mathrm{mmol}$ of aryl halide, $1.5 \mathrm{mmol}$ of alkene and base in 2 $\mathrm{mL}$ of solvent. ${ }^{\mathrm{b}}$ Determined by ${ }^{1} \mathrm{H}$ NMR using diphenylmethane as internal standard. In parenthesis, yield after flash chromatography for the pure compound. ${ }^{c}$ Ref. ${ }^{9}{ }^{\mathrm{d}}$ Regioisomeric ratio $\alpha / \beta: 1 / 10$. ${ }^{\mathrm{e}}$ Regioisomeric ratio $\alpha / \beta: 1 / 5$. ${ }^{\mathrm{f}}$ Regioisomeric ratio $\alpha / \beta: 1 / 6$. ${ }^{\mathrm{g}} \mathrm{TBAB}(1 \mathrm{mmol})$ was added. ${ }^{h}$ Regioisomeric ratio $\alpha / \beta$ : $1 / 18$. ${ }^{\mathrm{i}}$ Regioisomeric ratio $\alpha / \beta: 1 / 16$. ${ }^{j}$ Regioisomeric ratio $\alpha / \beta$ : $1 / 20 .{ }^{k}$ At $120{ }^{\circ} \mathrm{C} .{ }^{1}$ Regioisomeric ratio $\alpha / \beta: 1 / 17$. 
For the Mizoroki-Heck reactions in aqueous solvents tert-butyl acrylate and 4-chlorostyrene were again chosen as coupling partners of different aryl halides using dimeric palladacycles 2 and $\mathbf{6}$ and the polymer 3 and $\mathrm{Cy}_{2} \mathrm{NMe}$ as base (Table 2). When water was used as solvent, the reactions were performed at $120{ }^{\circ} \mathrm{C}$ bath temperature in a pressure tube. The arylation with 4chlorophenyl iodide took place very fast (2-4 h) with tert-butyl acrylate with all precatalysts using only $0.01 \mathrm{~mol} \%$ of $\mathrm{Pd}$ (Table 2, entries 1-3). However, the same arylation of 4chlorostyrene was much slower (12-30 h) (Table 2, entries 4-6). In the case of aryl bromides and chlorides, aqueous DMA (1:4) and TBAB as additive were used in order to achieve good yields. 4-Chlorophenyl bromide was coupled efficiently with tert-butyl acrylate and styrene under these reaction conditions with only $0.01 \mathrm{~mol} \%$ of $\mathrm{Pd}$ with good yields (Table 2, entries 7-11), as in neat DMA (Table 1, entries 8-13). In the case of 4-nitrophenyl chloride, the arylation in the presence of palladacycle 3 and 6 with 1 and $0.5 \mathrm{~mol} \%$ of $\mathrm{Pd}$, respectively (Table 2, entries 1215), took longer reaction times than in neat DMA (Table 1, entries 14-17). From all these experiments, it can be concluded that the polymeric palladacycle $\mathbf{3}$ showed a good catalytic activity similar to dimeric complexes $\mathbf{2}$ or $\mathbf{6}$, both in organic and aqueous solvents.

The arylation of acrylic systems such as the tert-butyl ester, acid, $N, N$-dimethyl amide, acrylonitrile, as well as methyl vinyl ketone with aryl iodides was carried out in DMF and in water (Table 3, entries 1-16). For the synthesis of tert-butyl $p$-chloro cinnamates, the Pd loading could be decreased to $0.001 \mathrm{~mol} \%\left(\mathrm{TON}=10^{5}\right)$, and the reaction was faster in $\mathrm{H}_{2} \mathrm{O}$ than in DMF (Table 3, entries 1 and 2). The opposite reactivity was observed when 4-methoxyphenyl iodide was coupled with tert-butyl acrylate (Table 3, entries 3 and 4). Acrylic acid was coupled quantitatively with 4-fluorophenyl iodide using $0.1 \mathrm{~mol} \%$ of Pd in both solvents ${ }^{14}$ (Table 3 , entries 5 and 6). When phenyl iodide was coupled with $N, N$-dimethylacrylamide, a lower Pd loading was necessary in DMF than in $\mathrm{H}_{2} \mathrm{O}$ to obtain the corresponding cinnamide in high yields (Table 3, entries 7 and 8). Acrylonitrile was the only acrylic system, which gave a mixture of $Z / E$-cinnamonitrile with $1 \mathrm{~mol} \%$ of Pd (Table 3, entries 9 and 10). Methyl vinyl ketone was arylated with phenyl, 4-hydroxyphenyl, and 4-methoxyphenyl iodide to provide the corresponding enones with better yields in DMF than in $\mathrm{H}_{2} \mathrm{O}$ using $0.01 \mathrm{~mol} \%$ of $\mathrm{Pd}$ (Table 3, entries 11-16). These enones can be hydrogenated ${ }^{14}$ to the corresponding saturated ketones, such as 4-( $p$-hydroxyphenyl) and 4-( $p$-methoxy)phenylbutan-2-one, which are natural odorous products extracted from Aloe wood with raspberry scent approved by the FDA for food use. These saturated ketones have recently been prepared by our group by a one-step synthesis based on the Mizoroki-Heck reaction of but-3-en-2-ol with aryl halides. ${ }^{12 \mathrm{k}}$ 
Table 2. Mizoroki-Heck reactions in aqueous solvents. Reaction conditions study ${ }^{\mathrm{a}}$

\begin{tabular}{|c|c|c|c|c|c|c|c|c|}
\hline Entry & $\operatorname{ArX}$ & Alkene & $\begin{array}{c}\text { Cat. } \\
(\mathrm{Pd}, \\
\mathrm{mol} \%)\end{array}$ & Additive & Solvent & $\begin{array}{c}\mathrm{t} \\
\text { (h) }\end{array}$ & Product & $\begin{array}{l}\text { Yield } \\
(\%)^{b}\end{array}$ \\
\hline 1 & $\begin{array}{l}4-\mathrm{Cl}- \\
\mathrm{C}_{6} \mathrm{H}_{4} \mathrm{I}\end{array}$ & $\mathrm{CH}_{2}=\mathrm{CHCO}_{2} \mathrm{Bu}^{t}$ & $2(0.01)$ & - & $\mathrm{H}_{2} \mathrm{O}$ & 3 & $4-\mathrm{ClC}_{6} \mathrm{H}_{4}$ & $94^{\mathrm{c}}$ \\
\hline 2 & & & $\mathbf{3}(0.01)$ & - & & 4 & & $99(88)$ \\
\hline 3 & & & $6(0.01)$ & - & & 2 & & 99 \\
\hline 4 & & $\begin{array}{c}\mathrm{CH}_{2}=\mathrm{CHC}_{6} \mathrm{H}_{4-}^{-} \\
4-\mathrm{Cl}\end{array}$ & $2(0.01)$ & - & & 30 & $4-\mathrm{ClC}_{6} \mathrm{H}_{4}$ & $96^{\mathrm{d}, \mathrm{e}}(79)$ \\
\hline 5 & & & $\mathbf{3}(0.01)$ & - & & 23 & & $96^{\mathrm{f}}(82)$ \\
\hline 6 & & & $6(0.01)$ & - & & 12 & & $97^{\mathrm{g}}$ \\
\hline 7 & $\begin{array}{c}4-\mathrm{Cl}- \\
\mathrm{C}_{6} \mathrm{H}_{4} \mathrm{Br}\end{array}$ & $\mathrm{CH}_{2}=\mathrm{CHCO}_{2} \mathrm{Bu}^{t}$ & $\mathbf{2}(0.01)$ & TBAB & $\mathrm{DMA}^{\mathrm{h}}$ & 14 & $\mathrm{CO}_{2} \mathrm{Bu}^{t}$ & $85^{\mathrm{c}}$ \\
\hline 8 & & & $\mathbf{3}(0.01)$ & & & 14 & & 99 \\
\hline 9 & & $\mathrm{CH}_{2}=\mathrm{CHPh}$ & $\mathbf{2}(0.01)$ & & & 14 & $4-\mathrm{ClC}_{6} \mathrm{H}_{4}$ & $95^{\mathrm{i}}(84)$ \\
\hline 10 & & & $\mathbf{3}(0.01)$ & & & 24 & & $86^{\mathrm{f}}$ \\
\hline 11 & & & $6(0.01)$ & & & 14 & & $91^{\mathrm{f}}$ \\
\hline 12 & $\begin{array}{l}4-\mathrm{NO}_{2-} \\
\mathrm{C}_{6} \mathrm{H}_{4} \mathrm{Cl}\end{array}$ & $\mathrm{CH}_{2}=\mathrm{CHCO}_{2} \mathrm{Bu}^{t}$ & $3(1)$ & TBAB & $\mathrm{DMA}^{\mathrm{h}}$ & 20 & $4-\mathrm{NO}_{2} \mathrm{C}_{6} \mathrm{H}_{4}$ & 81 \\
\hline 13 & & & $6(0.5)$ & & & 14 & & 88 \\
\hline 14 & & $\mathrm{CH}_{2}=\mathrm{CHPh}$ & $3(1)$ & & & 20 & $4-\mathrm{NO}_{2} \mathrm{C}_{6} \mathrm{H}_{4} \smile \mathrm{Ph}$ & $88^{\mathrm{j}}$ \\
\hline 15 & & & $6(0.5)$ & & & 14 & & $95^{\mathrm{e}}(89)$ \\
\hline
\end{tabular}

${ }^{a}$ The reactions were carried out using $1 \mathrm{mmol}$ of aryl halide, $1.5 \mathrm{mmol}$ of alkene and $\mathrm{Cy}_{2} \mathrm{NMe}$, $1.5 \mathrm{~mL}$ of solvent in a pressure tube. ${ }^{\mathrm{b}}$ Determined by ${ }^{1} \mathrm{H}$ NMR using diphenylmethane as internal standard. In parenthesis, yield after flash chromatography for the pure compound. ${ }^{c}$ Ref. $^{12 g}$ ${ }^{\mathrm{d}}$ Ref. ${ }^{12 \mathrm{e}}{ }^{\mathrm{e}}$ Regioisomeric ratio $\alpha / \beta: 1 / 16 .{ }^{\mathrm{f}}$ Regioisomeric ratio $\alpha / \beta: 1 / 10 .{ }^{g}$ Regioisomeric ratio $\alpha / \beta: 1 / 6 .{ }^{\mathrm{h}} \mathrm{DMA} / \mathrm{H}_{2} \mathrm{O}: 4 / 1 .{ }^{\mathrm{i}}$ Regioisomeric ratio $\alpha / \beta: 1 / 12 .{ }^{\mathrm{j}}$ Regioisomeric ratio $\alpha / \beta: 1 / 14$.

Methyl itaconate was stereoselectively phenylated in high yield using water as solvent and $0.1 \mathrm{~mol} \%$ of Pd (Table 3, entry 17). Other substituted acrylic systems such as, crotonic acid and cinnamonitrile were arylated with 4-fluorophenyl iodide in water with high diastereoselectivity in favor of the $E$-isomer (Table 3, entries 18 and 19). The reaction of crotonic acid resulted in lower conversion compared with that of cinnamonitrile and afforded isomeric products. For the coupling of aryl bromides and acrylic systems, aqueous DMA as solvent and TBAB as additive were used (Table 3, entries 20-23). However, in the case of aryl chlorides, neat DMA and TBAB proved the best reaction conditions (Table 3, entries 24 and 25). Most of these arylation reactions have been previously carried out using palladacycle 2 with similar results. ${ }^{12 \mathrm{f}}$ 
Table 3. Mizoroki-Heck reactions with acrylic derivatives using the polymeric palladacycle $3^{\text {a }}$

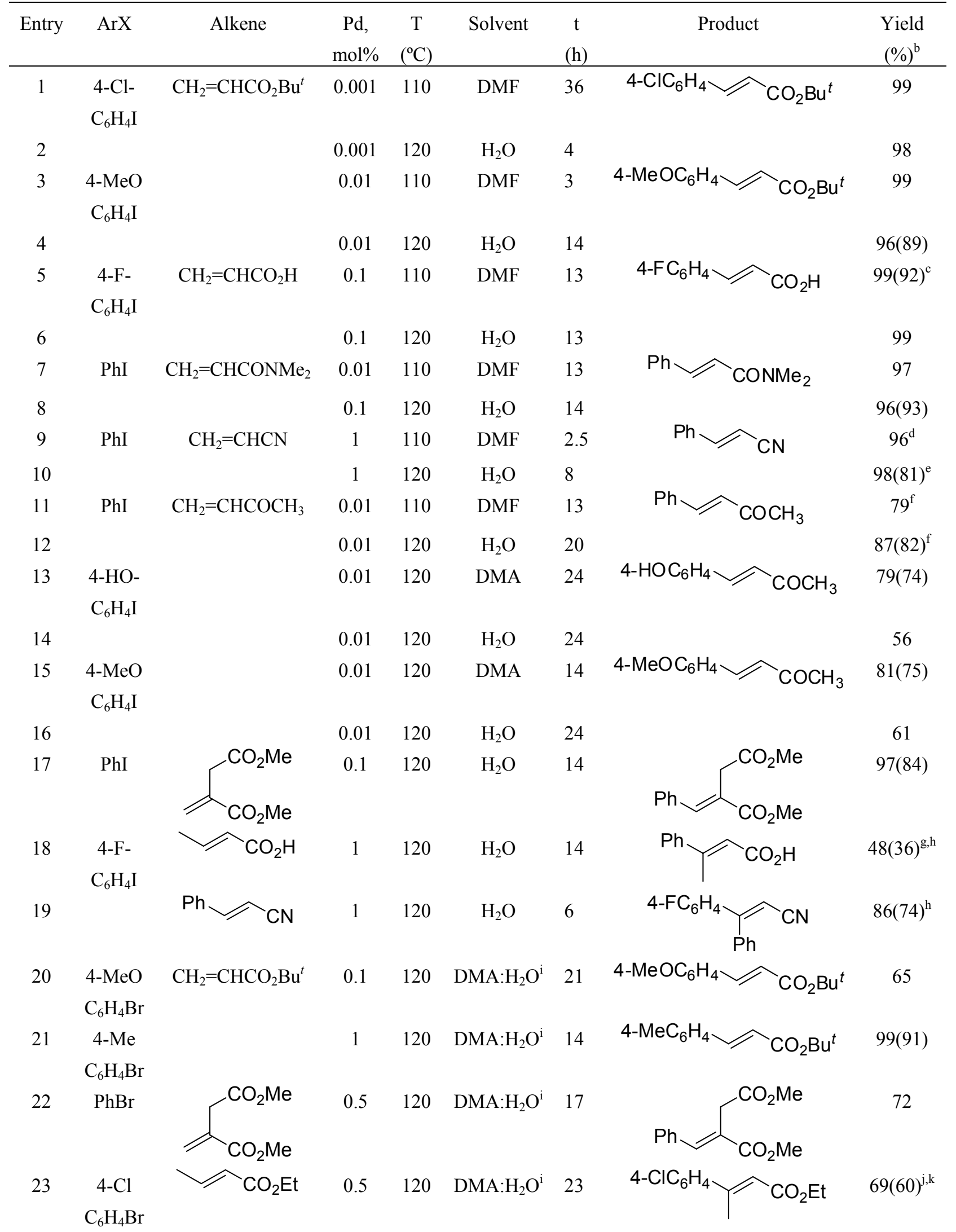




\begin{tabular}{|c|c|c|c|c|c|c|c|c|}
\hline 24 & 4-Ac & $\mathrm{CH}_{2}=\mathrm{CHCO}_{2} \mathrm{Bu}^{t}$ & 1 & 120 & $\mathrm{DMA}^{1}$ & 22 & $4-\mathrm{AcC}_{6} \mathrm{H}_{4} \smile \mathrm{CO}_{2} \mathrm{Bu}^{t}$ & $76(62)$ \\
\hline 25 & $\begin{array}{c}\mathrm{C}_{6} \mathrm{H}_{4} \mathrm{Cl} \\
4-\mathrm{Me} \\
\mathrm{C}_{6} \mathrm{H}_{4} \mathrm{Cl}\end{array}$ & & 2 & 120 & $\mathrm{DMA}^{1}$ & 36 & 4- $\mathrm{MeC}_{6} \mathrm{H}_{4} \smile \mathrm{CO}_{2} \mathrm{Bu}^{t}$ & 36 \\
\hline
\end{tabular}

${ }^{\mathrm{a}}$ The reactions were carried out using $1 \mathrm{mmol}$ of aryl halide, $1.5 \mathrm{mmol}$ of alkene and $\mathrm{Cy}_{2} \mathrm{NMe}$, $1.5 \mathrm{~mL}$ of solvent in a pressure tube in the case of water, $2 \mathrm{~mL}$ in organic solvents, or $5 \mathrm{~mL}$ in the case of aqueous DMA. ${ }^{b}$ Determined by ${ }^{1} \mathrm{H}$ NMR using diphenylmethane as internal standard. In parenthesis, yield after flash chromatography for the pure compound. ${ }^{c}$ After recrystallization. ${ }^{\mathrm{d}} Z / E: \quad 1 / 5 .{ }^{\mathrm{e}} Z / E: \quad 1 / 4 .{ }^{\mathrm{f}} 10 \%$ of 4 -phenylbutan-2-one was also obtained. ${ }^{\mathrm{g}} \mathrm{A} 6 \%$ of $3-(p-$ fluorophenyl)but-3-enoic acid and $2 \%$ of 4 -( $p$-fluorophenyl)but-3-enoic acid were also obtained. h $Z / E$ : 4/96. ${ }^{\mathrm{i}} 4: 1$ and $\mathrm{TBAB}(1 \mathrm{mmol})$ as additive. ${ }^{\mathrm{j}} Z / E: 9 / 91 .{ }^{\mathrm{k}} \mathrm{A} 12 \%$ of ethyl $3-(p-$ chlorophenyl)but-3-enoate was also obtained. ${ }^{1}$ In the presence of TBAB $(1 \mathrm{mmol})$ as additive.

Hydroxylated stilbenoids, specially resveratrol [3,4',5-trihydroxy-(E)-stilbene], are very important class of natural products with important biological activity. ${ }^{15}$ The stilbenoid unit is used in molecular photonics and optoelectronics. ${ }^{16}$ In addition, methoxylated stilbenoids have shown activity against several human cancer cell lines ${ }^{17}$ and are potent CYP1B1 inhibitors valuable for the development for chemopreventive and therapeutic agents for cancer. ${ }^{18}$ The arylation of styrenes for the synthesis of methoxylated stilbenoids have been previously carried out in the presence of palladacycle $2 .{ }^{12 \mathrm{e}}$ Now, the reaction promoted by polymeric palladacycle 3 and related complex 6 was performed in aqueous DMA as solvent in the presence of TBAB as additive and $\mathrm{Cy}_{2} \mathrm{NMe}$ as base (Table 4). Thus, methylated resveratrol was prepared by arylation of 4-methoxystyrene with 3,5-dimethoxyiodobenzene ${ }^{19}$ using 2 or 3 (Table 4, entries 1 and 2). 4Methoxyphenyl bromide and 2-bromothiophene needed a higher $\mathrm{Pd}$ loading than 3,5dimethoxyiodobenzene, affording the corresponding stilbenes in high yields after reaction with 3,4-dimethoxystyrene with both palladacycles 3 and $\mathbf{6}$ as precatalysts (Table 4, entries 3-6). It was reported that an anti-cancer agent DMU-212 [(E)-3,4,5,4'-tetramethoxystilbene $]^{20}$ was prepared in $43 \%$ yield by coupling of 4-methoxystyrene with 3,4,5-trimethoxybromobenzene using $4 \mathrm{~mol} \%$ of trans-[bis(2-ethyl-2-oxazoline- $\kappa^{1} N$ )palladium(II)dichloride at $153{ }^{\circ} \mathrm{C}^{20}$ We obtained this compound in $75 \%$ yield in our catalytic system using 3 or 6 in its 1 or $0.5 \mathrm{~mol} \%$ of Pd loading at $120{ }^{\circ} \mathrm{C}$ (Table 4, entries 7 and 8). 
Table 4. Mizoroki-Heck reaction with styrenes using palladacycles ${ }^{\mathrm{a}}$

Entry

${ }^{\mathrm{a}}$ The reactions were carried out using $1 \mathrm{mmol}$ of aryl halide, $1.5 \mathrm{mmol}$ of alkene and $\mathrm{Cy}_{2} \mathrm{NMe}$, $1 \mathrm{mmol}$ of TBAB, and $5 \mathrm{~mL}$ of solvent in a pressure tube at $120^{\circ} \mathrm{C}$. ${ }^{\mathrm{b}}$ Determined by ${ }^{1} \mathrm{H}$ NMR using diphenylmethane as internal standard. In parenthesis, yield after flash chromatography for the pure compound. ${ }^{c} \mathrm{See}$, reference $12 \mathrm{e}$. ${ }^{\mathrm{d}}$ Regioisomeric ratio $\alpha / \beta: 1 / 6 .{ }^{e}$ Regioisomeric ratio $\alpha / \beta$ : 1/9. ${ }^{\mathrm{f}}$ Regioisomeric ratio $\alpha / \beta: 1 / 10$. ${ }^{\mathrm{g}}$ Regioisomeric ratio $\alpha / \beta: 1 / 11$. ${ }^{\mathrm{h}}$ Regioisomeric ratio $\alpha / \beta$ : $1 / 16$. ${ }^{\mathrm{i}}$ Regioisomeric ratio $\alpha / \beta: 1 / 19$. ${ }^{\mathrm{j}}$ Regioisomeric ratio $\alpha / \beta: 1 / 8$.

A related intramolecular Mirozoki-Heck reaction is the annulation reaction between internal alkynes and 2-halo substituted aromatic aldehydes and anilines for the synthesis of indenones and indoles, respectively, developed by Larock and col. ${ }^{21}$ Our previous studies with $\mathbf{1}$ revealed that similar cyclizations took place efficiently using $\mathrm{K}_{2} \mathrm{CO}_{3}$ as base and TBAB as additive in DMF at $130{ }^{\circ} \mathrm{C}$ (Scheme 2 and Table 5). ${ }^{9 b}$ Under these reaction conditions, 3,4diphenylindenone was obtained by coupling of 2-bromobenzaldehyde with 1,2diphenylacetylene in the presence of $\mathbf{1}$ in $98 \%$ yield (Table 5, entry 1) and in the presence of $\mathbf{3}$ 
in $40 \%$ yield (entry 2). However, the use of a tertiary amine instead of $\mathrm{K}_{2} \mathrm{CO}_{3}$ allowed to increase the yield from to $88 \%$ in a shorter time (entry 3). Replacement of DMF with aqueous DMA also improved the yield to $71 \%$ (entry 4). The use of $\mathrm{Cy}_{2} \mathrm{NMe}$ in aqueous DMA induced an efficient formation of the indenone in $92 \%$ isolated yield (entry 5). The use of the dimeric palladacycle $\mathbf{6}$ gave the same results in shorter reaction time (entry 6).<smiles>O=Cc1ccccc1Br</smiles><smiles>C(#Cc1ccccc1)c1ccccc1</smiles>
cat. $(1 \mathrm{~mol} \% \mathrm{Pd})$ base, TBAB, solvent, $T$<smiles>O=C1C(c2ccccc2)=C(c2ccccc2)c2ccccc21</smiles>

Scheme 2. Synthesis of 2,3-diphenylindenone.

Table 5. Synthesis of 2,3-diphenylindenone ${ }^{\mathrm{a}}$

\begin{tabular}{|c|c|c|c|c|c|c|}
\hline Entry & Cat. & Base & Solvent & $\mathrm{T}\left({ }^{\circ} \mathrm{C}\right)$ & $\mathrm{t}(\mathrm{h})$ & Yield $(\%)^{b}$ \\
\hline 1 & 1 & $\mathrm{~K}_{2} \mathrm{CO}_{3}$ & DMF & 130 & 2 & $98^{\mathrm{c}}$ \\
\hline 2 & 3 & $\mathrm{~K}_{2} \mathrm{CO}_{3}$ & $\mathrm{DMF}$ & 130 & 16 & 40 \\
\hline 3 & 3 & $\mathrm{Cy}_{2} \mathrm{NMe}$ & DMF & 130 & 8 & $88(80)$ \\
\hline 4 & 3 & $\mathrm{~K}_{2} \mathrm{CO}_{3}$ & $\mathrm{DMA} / \mathrm{H}_{2} \mathrm{O}^{\mathrm{d}}$ & 120 & 9 & 71 \\
\hline 5 & 3 & $\mathrm{Cy}_{2} \mathrm{NMe}$ & $\mathrm{DMA} / \mathrm{H}_{2} \mathrm{O}^{\mathrm{d}}$ & 120 & 6 & $92(81)$ \\
\hline 6 & 6 & $\mathrm{Cy}_{2} \mathrm{NMe}$ & $\mathrm{DMA} / \mathrm{H}_{2} \mathrm{O}^{\mathrm{d}}$ & 120 & 3 & 92 \\
\hline
\end{tabular}

${ }^{\mathrm{a}}$ The reactions were carried out using $1 \mathrm{mmol}$ of aryl halide, $1.5 \mathrm{mmol}$ of alkyne and base, 1 mmol of TBAB, $2 \mathrm{~mL}$ for DMF and $5 \mathrm{~mL}$ for aqueous DMA. ${ }^{\mathrm{b}}$ Determined by ${ }^{1} \mathrm{H}$ NMR using diphenylmethane as internal standard. In parenthesis, yield after flash chromatography for the pure compound. ${ }^{\mathrm{c}}$ Ref. $9 \mathrm{~b} .{ }^{\mathrm{d}} 4 / 1$.

The reaction of 2-iodoaniline with tolane has been performed previously in DMF and with $\mathrm{K}_{2} \mathrm{CO}_{3}$ using complex $\mathbf{1}^{9 \mathrm{~b}}$ providing the corresponding indole (Scheme 3 and Table 6, entry 1). These conditions were also the most appropriate when polymeric and dimeric palladacycles 3 and 6 were used as precatalysts (Table 6, entries 2 and 3). The reaction using $\mathrm{Cy}_{2} \mathrm{NMe}_{\mathrm{M}}$ aqueous DMA at $120^{\circ} \mathrm{C}$ failed (Table 6, entry 4 ).
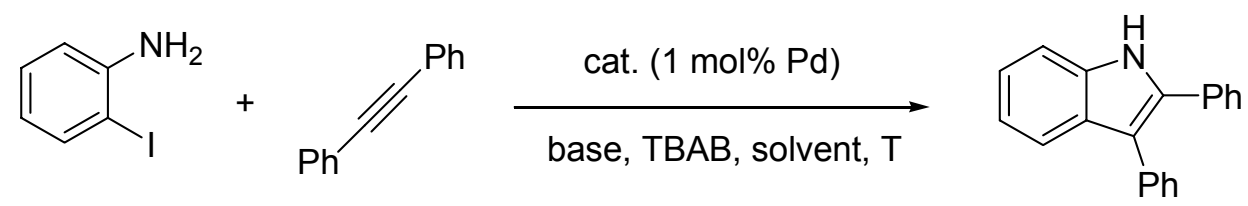

Scheme 3. Synthesis of 2,3-diphenylindole. 
Table 6. Synthesis of 2,3-diphenylindole ${ }^{\mathrm{a}}$

\begin{tabular}{ccccccc}
\hline Entry & Cat. & Base & Solvent & $\mathrm{T}\left({ }^{\circ} \mathrm{C}\right)$ & $\mathrm{t}(\mathrm{h})$ & Yield $(\%)^{\mathrm{b}}$ \\
\hline 1 & $\mathbf{1}$ & $\mathrm{K}_{2} \mathrm{CO}_{3}$ & DMF & 130 & 10 & $98(50)^{\mathrm{c}}$ \\
2 & $\mathbf{3}$ & $\mathrm{K}_{2} \mathrm{CO}_{3}$ & $\mathrm{DMF}$ & 130 & 10 & $99(97)$ \\
3 & $\mathbf{6}$ & $\mathrm{K}_{2} \mathrm{CO}_{3}$ & DMF & 130 & 9 & 96 \\
4 & $\mathbf{3}$ & $\mathrm{Cy}_{2} \mathrm{NMe}$ & $\mathrm{DMA} / \mathrm{H}_{2} \mathrm{O}^{\mathrm{d}}$ & 120 & 14 & 0 \\
\hline
\end{tabular}

${ }^{\text {a }}$ The reactions were carried out using $1 \mathrm{mmol}$ of aryl halide, $1.5 \mathrm{mmol}$ of alkyne and base, $1 \mathrm{mmol}$ of TBAB, $2 \mathrm{~mL}$ for DMF and $5 \mathrm{~mL}$ for aqueous DMA. ${ }^{b}$ Determined by ${ }^{1} \mathrm{H}$ NMR using diphenylmethane as internal standard. In parenthesis after flash chromatography for the pure compound. ${ }^{\mathrm{c}}$ Ref. 9b. ${ }^{\mathrm{d}} 4 / 1$.

Recycling experiments of palladacycle $\mathbf{3}$ using DMF or water as solvents were performed for the reaction between acrylic derivatives and aryl iodides (Table 7). The arylation of methyl acrylate with iodobenzene in DMF at $110{ }^{\circ} \mathrm{C}$ with $\mathrm{Et}_{3} \mathrm{~N}$ as base was carried out with an initial 0.1 mol\% of Pd loading. After 8 consecutive cycles the yield was maintained above $90 \%$ after $10 \mathrm{~h}$ reaction time. The content of $\mathrm{Pd}$ in the crude products was in the range of 2.9-37.2 ppm, determined by ICP-OES. A similar study, but with 4-chloroiodobenzene and tert-butyl acrylate using water as solvent and $\mathrm{Cy}_{2} \mathrm{NMe}$ as base, gave almost quantitative yields during 8 cycles, keeping the reaction time between 2 and $3 \mathrm{~h}$. The Pd leaching in the crude products was in the range of 9.7-13.4 ppm, and the leaching of Pd from the polymer was $0.4-5 \%$ in the experiments with DMF, and $2-2.7 \%$ in $\mathrm{H}_{2} \mathrm{O}$. That means that the polymer degradates much more in DMF than in water. In addition, XPS analyses of the starting and recycled polymer detected only $\operatorname{Pd}(\mathrm{II})$. When these reactions were performed in the presence of 300 equiv. of $\mathrm{Hg}(0)$ by $\mathrm{Pd}$ equiv., the reaction did not take place after $5 \mathrm{~h}$ reaction time, indicating that the real catalyst are the Pd nanoparticles and that the polymer is acting as a source of these colloids. This has also been confirmed in the case of other palladacycles. ${ }^{4,5,22}$ The decomposition of this polymeric palladacycle to Pd nanoparticles took place similarly in organic and in aqueous media, which means that it is not necessary to employ other solid supports to increase the solubility in organic or aqueous solvents.

Using polymeric complex 3 several recycling experiments were carried out using the same batch of polymer in different arylation reactions either using DMF or water as solvents (Table 7). The same couplings shown in Tables 1-3 were performed using the recycled polymer with the same results. Thus, acrylonitrile, methyl vinyl ketone and $N, N$-dimethylacrylamide were arylated with iodobenzene and tert-butyl acrylate with 4-chloroiodobenzene either in DMF or in water in four consecutive runs with recycled $\mathbf{3}$ (Table 7). The corresponding products were obtained with the same yield in the same reaction time than using the new polymer, and also without contamination of the product on the subsequent run. 
Table 7. Recycling experiments for the Mizoroki-Heck reaction with acrylic derivatives using the polymeric palladacycle $3^{\text {a }}$

\begin{tabular}{|c|c|c|c|c|c|c|c|c|}
\hline Run & ArX & Alkene & $\begin{array}{c}\mathrm{Pd}, \\
\mathrm{mol} \%\end{array}$ & $\begin{array}{c}\mathrm{T} \\
\left({ }^{\circ} \mathrm{C}\right)\end{array}$ & $\begin{array}{l}\text { Solvent/ } \\
\text { Base }\end{array}$ & $\begin{array}{c}\mathrm{t} \\
\text { (h) }\end{array}$ & Product & $\begin{array}{l}\text { Yield } \\
(\%)^{b}\end{array}$ \\
\hline 1 & $\mathrm{PhI}$ & $\mathrm{CH}_{2}=\mathrm{CHCO}_{2} \mathrm{Me}$ & 0.1 & 110 & $\begin{array}{l}\mathrm{DMF} / \\
\mathrm{Et}_{3} \mathrm{~N}\end{array}$ & 1.6 & $\mathrm{O}_{2} \mathrm{Me}$ & 97 \\
\hline 2 & & & & & & 2 & & 97 \\
\hline 3 & & & & & & 2.5 & & 92 \\
\hline 4 & & & & & & 3 & & 97 \\
\hline 5 & & & & & & 4 & & 96 \\
\hline 6 & & & & & & 4.5 & & 94 \\
\hline 7 & & & & & & 6.7 & & 95 \\
\hline 8 & & & & & & 10 & & 90 \\
\hline 1 & $\begin{array}{l}4-\mathrm{Cl}- \\
\mathrm{C}_{6} \mathrm{H}_{4} \mathrm{I}\end{array}$ & $\mathrm{CH}_{2}=\mathrm{CHCO}_{2} \mathrm{Bu}^{t}$ & 0.1 & 120 & $\begin{array}{c}\mathrm{H}_{2} \mathrm{O} / \\
\mathrm{Cy}_{2} \mathrm{NMe}\end{array}$ & 2 & $\mathrm{CO}_{2} \mathrm{Bu}^{t}$ & 99 \\
\hline 2 & & & & & & 2.5 & & 99 \\
\hline 3 & & & & & & 2.5 & & 99 \\
\hline 4 & & & & & & 2 & & 93 \\
\hline 5 & & & & & & 2.5 & & 96 \\
\hline 6 & & & & & & 2.5 & & 98 \\
\hline 7 & & & & & & 3 & & 99 \\
\hline 8 & & & & & & 3 & & 98 \\
\hline 1 & PhI & $\mathrm{CH}_{2}=\mathrm{CHCN}$ & 1 & 110 & $\begin{array}{c}\mathrm{DMF} / \\
\mathrm{Cy}_{2} \mathrm{NMe}\end{array}$ & 2.5 & & $96^{c}$ \\
\hline 2 & & $\mathrm{CH}_{2}=\mathrm{CHCOCH}_{3}$ & 0.1 & 110 & $\begin{array}{c}\mathrm{DMF} / \\
\mathrm{Cy}_{2} \mathrm{NMe}\end{array}$ & 7 & $\mathrm{CH}_{3}$ & 95 \\
\hline 3 & & $\mathrm{CH}_{2}=\mathrm{CHCONMe}_{2}$ & 0.1 & 110 & $\begin{array}{c}\mathrm{DMF} / \\
\mathrm{Cy}_{2} \mathrm{NMe}\end{array}$ & 14 & $\mathrm{NMe}_{2}$ & 99 \\
\hline 4 & $\begin{array}{c}4-\mathrm{Cl} \\
\mathrm{C}_{6} \mathrm{H}_{4} \mathrm{I}\end{array}$ & $\mathrm{CH}_{2}=\mathrm{CHCO}_{2} \mathrm{Bu}^{t}$ & 0.01 & 110 & $\begin{array}{c}\mathrm{DMF} / \\
\mathrm{Cy}_{2} \mathrm{NMe}\end{array}$ & 2.5 & 4-CIC & 99 \\
\hline 1 & $\mathrm{PhI}$ & $\mathrm{CH}_{2}=\mathrm{CHCN}$ & 1 & 120 & $\begin{array}{c}\mathrm{H}_{2} \mathrm{O} / \\
\mathrm{Cy}_{2} \mathrm{NMe}\end{array}$ & 8 & & $98^{\mathrm{d}}$ \\
\hline 2 & & $\mathrm{CH}_{2}=\mathrm{CHCOCH}_{3}$ & 0.1 & 120 & $\begin{array}{c}\mathrm{H}_{2} \mathrm{O} / \\
\mathrm{Cy}_{2} \mathrm{NMe}\end{array}$ & 8.5 & $\mathrm{CH}_{3}$ & 92 \\
\hline 3 & & $\mathrm{CH}_{2}=\mathrm{CHCONMe}_{2}$ & 0.1 & 120 & $\begin{array}{c}\mathrm{H}_{2} \mathrm{O} / \\
\mathrm{Cy}_{2} \mathrm{NMe}\end{array}$ & 14 & $\mathrm{NMe}_{2}$ & 99 \\
\hline 4 & $\begin{array}{l}4-\mathrm{Cl} \\
\mathrm{C}_{6} \mathrm{H}_{4} \mathrm{I}\end{array}$ & $\mathrm{CH}_{2}=\mathrm{CHCO}_{2} \mathrm{Bu}^{t}$ & 0.01 & 120 & $\begin{array}{c}\mathrm{H}_{2} \mathrm{O} / \\
\mathrm{Cy}_{2} \mathrm{NMe}\end{array}$ & 3 & $\widehat{\mathrm{CO}_{2} \mathrm{Bu}^{t}}$ & 99 \\
\hline
\end{tabular}

${ }^{a}$ The reactions were carried out using $1 \mathrm{mmol}$ of aryl halide, $1.5 \mathrm{mmol}$ of alkene and base, 1.5 $\mathrm{mL}$ of solvent in a pressure tube in the case of water or $2 \mathrm{~mL}$ in the case of DMF. ${ }^{b}$ Determined by ${ }^{1} \mathrm{H}$ NMR using diphenylmethane as internal standard. ${ }^{\mathrm{c}} Z / E: 1 / 5 .{ }^{\mathrm{d}} Z / E: 1 / 4$. 
As conclusion, the high catalytic efficiency of the the polymeric palladacycle derived from Kaiser oxime resin similar to that of related unsupported dimeric palladacycles was observed in the Mizoroki-Heck reaction. This polymer showed a good catalytic activity, not only in organic but also in aqueous media, for aryl iodides, bromides and activated chlorides with high TONs, under aerobic conditions at relatively lower temperature. Electron-poor and electron-rich alkenes can be arylated with high regio- and diastereoselectivity with high functional group tolerance. It is worthy to mention that the anti-cancer agent DMU-212 [(E)-3,4,5,4'-tetramethoxystilbene] has been prepared in one step for commercially available materials with the highest yield described so far. Annulation reactions of 2-halo substituted aldehyde and aniline with tolane were also carried out with high yields under appropriate reaction conditions. Recycling experiments showed a high stability and activity of this polymer during at least 8 cycles in organic and aqueous solvents, specially in neat water, with low levels of Pd leaching. It is remarkable that the analyzed crude products in the recycling experiments contain from 2.9 to $37.2 \mathrm{ppm} \mathrm{Pd}$ and that the required purity for active pharmaceutical ingredients (APIs) must be kept typically from 2-20 ppm. ${ }^{23}$ Therefore, this polymeric palladacycle could be a good precatalyst to be implemented in pharmaceutical processes. XPS analysis and poisoning studies indicated clearly that this polymer is a precatalyst acting as a source of Pd nanoparticles. Based on the studies recently performed with a membrane reactor it was demonstrated that the real catalyst are both the $\operatorname{Pd}(0)$ atoms and $\mathrm{Pd}(\mathrm{II})$ reaction intermediates, which have leached into the solution from the clusters or from an oxidative addition of the aryl halide from the cluster, respectively, and not the cluster itself. ${ }^{24}$ From our studies, it can be concluded that this polymer is a general precatalyst for MizorokiHeck reactions suitable to be used in the reaction media where related dimeric palladacycles worked well.

\section{Experimental Section}

General. The reagents and solvents were obtained from commercial sources and were generally used without further purification. Flash chromatography was performed on silica gel 60 (0.040-0.063 mm, Merck). Thin layer chromatography was perfomed on Polygram ${ }^{\circledR}$ SIL $\mathrm{G} / \mathrm{UV}_{254}$ plates. Mps were determined on a Reichert Thermovar apparatus. Gas chromatographic analyses were performed on a HP-6890 instrument equipped with a WCOT HP-1 fused silica capillary column. IR data were measured on a Nicolet Impact-400D-FT spectrophotometer in $\mathrm{cm}^{-1}$. ${ }^{1} \mathrm{H}$ NMR spectra were recorded on a Bruker AC-300 (300 MHz) and Bruker AC-400 (400 $\mathrm{MHz}$ ). Chemical shifts are reported in ppm using tetramethylsilane (TMS, $0.00 \mathrm{ppm}$ ) as internal standard. ${ }^{13} \mathrm{C}$ NMR spectra were recorded at 75 or $100 \mathrm{MHz}$. EI-MS were measured on a Mass Selective Detector G2579A from Agilent Technologies $5973 \mathrm{~N}$ in $\mathrm{m} / \mathrm{z}$ (rel. intensity in \% of base peak). The catalysts were weighed up in an electronic microscale (Sartorius, XM1000P) with precision of $1 \mu \mathrm{g}$. ICP-OES analyses were performed in a Perkin-Elmer Optima 4300 spectrometer. X-Ray photoelectron spectroscopy (XPS) analyses were performed in a VG- 
Microtech Multilab 3000. Palladacycles 1 and 2 and Kaiser oxime resin are commercially available. Palladacycles 3 and $\mathbf{6}$ were prepared as described in ref. 12k.

A typical experimental procedure for the Mizoroki-Heck reaction of aryl iodides on water. A pressure tube was charged with the aromatic iodide $(1 \mathrm{mmol})$, alkene $(1.5 \mathrm{mmol}), \mathrm{Cy}_{2} \mathrm{NMe}$ $(0.320 \mathrm{~mL}, 1.5 \mathrm{mmol})$, catalyst 1 or $\mathbf{3}$ (see Tables) and water $(1.5 \mathrm{~mL})$. The mixture was stirred at $120^{\circ} \mathrm{C}$ (bath temperature), and the reaction progress was monitored by GLC. The reaction mixture was cooled to $\mathrm{rt}$, and an aqueous solution of $2 \mathrm{M} \mathrm{HCl}(10 \mathrm{~mL})$ was added. The mixture was poured into ethyl acetate $(40 \mathrm{~mL})$ and washed with $2 \mathrm{M} \mathrm{HCl}(2 \times 20 \mathrm{~mL})$ and $\mathrm{H}_{2} \mathrm{O}(2 \times 20$ $\mathrm{mL}$ ). The organic layer was dried over $\mathrm{MgSO}_{4}$, and the solvents were removed under vacuum (15 mm Hg). The reaction yield was calculated by ${ }^{1} \mathrm{H}-\mathrm{RMN}(300 \mathrm{MHz})$. The residue was purified by flash chromatography with hexane/ethyl acetate.

A typical experimental procedure for the Mizoroki-Heck reaction of aryl bromides and chlorides on aqueous solvents. A pressure tube was charged with the aryl bromide or chloride (1 mmol), alkene (1.5 mmol), $\mathrm{Cy}_{2} \mathrm{NMe}(0.320 \mathrm{~mL}, 1.5 \mathrm{mmol})$, catalyst (see Tables), $n$ tetrabutylammonium bromide $(322 \mathrm{mg}, 1 \mathrm{mmol})$, water $(1 \mathrm{~mL})$, and dimethylacetamide $(4 \mathrm{~mL})$. The mixture was stirred at $120^{\circ} \mathrm{C}$ (bath temperature), and the reaction progress was monitored by GLC. The reaction was cooled to $\mathrm{rt}$, and an aqueous solution of $2 \mathrm{M} \mathrm{HCl}(10 \mathrm{~mL})$ was added. The crude reaction was poured into ethyl acetate $(40 \mathrm{~mL})$ and washed with $2 \mathrm{M} \mathrm{HCl}(2 \times 20 \mathrm{~mL})$ and $\mathrm{H}_{2} \mathrm{O}(4 \times 20 \mathrm{~mL})$. The organic layer was dried over $\mathrm{MgSO}_{4}$, and the solvents were removed under vacuum $(15 \mathrm{~mm} \mathrm{Hg})$. The reaction yield was calculated by H-RMN (300 MHz). The residue was purified by flash chromatography with hexane/ethyl acetate.

A typical experimental procedure for the Mizoroki-Heck reaction in organic solvents. A mixture of aryl halide $(1 \mathrm{mmol})$, alkene $(1.5 \mathrm{mmol})$, amine $(1.5 \mathrm{mmol})$, TBAB (0.322 $\mathrm{g}, 1$ $\mathrm{mmol}$ ) in the case of aryl bromides and chlorides, and catalyst (see Tables), was dissolved in DMF or DMA (2 mL). The mixture was stirred at $120^{\circ} \mathrm{C}$ (bath temperature) and the reaction progress was monitored by GLC. The reaction was cooled to rt, and an aqueous solution of $2 \mathrm{M}$ $\mathrm{HCl}(10 \mathrm{~mL})$ was added. The crude reaction was poured into ethyl acetate $(40 \mathrm{~mL})$ and washed with $2 \mathrm{M} \mathrm{HCl}(2 \times 20 \mathrm{~mL})$ and $\mathrm{H}_{2} \mathrm{O}(4 \times 20 \mathrm{~mL})$. The organic layer was dried over $\mathrm{MgSO}_{4}$, and the solvents were removed under vacuum $(15 \mathrm{~mm} \mathrm{Hg})$. The reaction yield was calculated by ${ }^{1} \mathrm{H}-$ RMN (300 MHz). The residue was purified by flash chromatography with hexane/ethyl acetate.

A typical experimental procedure for the Heck reaction. Recycling experiments. The reaction was performed under the above described conditions: aromatic halide (1 mmol), alkene (1.5 mmol), base (1.5 mmol), 3 (see Table 7), solvent (1.5 mL $\mathrm{H}_{2} \mathrm{O}, 5 \mathrm{~mL} \mathrm{DMA} / \mathrm{H}_{2} \mathrm{O} 4: 1$ or 2 $\mathrm{mL} \mathrm{DMF})$ and TBAB (1 mmol), at the corresponding temperature. When the reaction was finished, the catalyst was filtered off using a porous plate G4, washed with ethyl acetate, and dried under vacuum for 20 minutes. The crude product was purified as described above. 
Synthesis of 2,3-diphenylindenone. A solution of 2-bromobenzaldehyde $(0.117 \mathrm{~mL}, 1 \mathrm{mmol})$, diphenylacetylene (267 mg, $1.5 \mathrm{mmol})$, dicyclohexylmethylamine $(0.321 \mathrm{~mL}, 1.5 \mathrm{mmol})$ or potassium carbonate $(277 \mathrm{mg}, 2 \mathrm{mmol}$ ), tetra- $n$-butylammonium bromide (322 mg, $1 \mathrm{mmol}), 1$ (1 mol \% Pd) in $N, N$-dimethylacetamide $(4 \mathrm{~mL})$ and water $(1 \mathrm{~mL})$ or DMF $(4 \mathrm{~mL})$ was stirred at $120-130{ }^{\circ} \mathrm{C}$ and the reaction progress was analyzed by GLC. After the reaction was completed, the resulting solution was cooled to rt, poured into ethyl acetate $(40 \mathrm{~mL})$ and washed with $\mathrm{H}_{2} \mathrm{O}$ ( 3 x $30 \mathrm{~mL}$ ). The organic layer was dried over $\mathrm{MgSO}_{4}$ and evaporated (15 mm $\mathrm{Hg}$ ) and, the residue was purified by flash chromatography with hexane/ethyl acetate to afford the indenone as a red solid. Mp $147-149{ }^{\circ} \mathrm{C}$ (lit. ${ }^{25} \mathrm{mp} 152-154{ }^{\circ} \mathrm{C}$ ).

Synthesis of 2,3-diphenylindole. A solution of 2-iodoaniline (224 $\mathrm{mg}, 1 \mathrm{mmol})$, diphenylacetylene $(267 \mathrm{mg}, 1.5 \mathrm{mmol})$, potassium carbonate $(277 \mathrm{mg}, 2 \mathrm{mmol})$, tetra- $n$ butylammonium bromide ( $65 \mathrm{mg}, 0.2 \mathrm{mmol}), 1$ (1 mol \% Pd) DMF (4 mL) was stirred at $130{ }^{\circ} \mathrm{C}$, and the reaction progress was analyzed by GLC. After the reaction was completed, the resulting solution was cooled at $\mathrm{rt}$, poured into ethyl acetate $(40 \mathrm{~mL})$ and washed with $\mathrm{H}_{2} \mathrm{O}(3 \mathrm{x} 30 \mathrm{~mL})$. The organic layer was dried over $\mathrm{MgSO}_{4}$ and evaporated $(15 \mathrm{~mm} \mathrm{Hg}$ ) and, the residue was purified by flash chromatography with hexane/ethyl acetate to afford the indole as a yellow solid. Mp 120-121 ${ }^{\circ} \mathrm{C}$ (lit. ${ }^{26} \mathrm{mp} 124-125^{\circ} \mathrm{C}$ )

(E)-2-(3,4-Dimethoxystyryl)thiophene. White solid; m.p. $108-110{ }^{\circ} \mathrm{C} ; R_{f}=0.28$ (hexane/ethyl acetate 5:1); ${ }^{1} \mathrm{H}-\mathrm{RMN}\left(300 \mathrm{MHz}, \mathrm{CDCl}_{3}\right): \delta=7.16(\mathrm{~d}, 1 \mathrm{H}, J=4.8 \mathrm{~Hz}, \mathrm{ArCH}), 7.10(\mathrm{~d}, 1 \mathrm{H}, J=$ 16.2 Hz, $\left.\mathrm{CH}_{\text {trans }}\right), 7.07-6.97$ (m, 4H, ArH), 6.87 (d, 1H, J=16.2 Hz, $\left.\mathrm{CH}_{\text {trans }}\right), 6.83$ (d, $1 \mathrm{H}, J=8.7$ $\mathrm{Hz}, \mathrm{ArH}), 3.92\left(\mathrm{~s}, 3 \mathrm{H}, \mathrm{CH}_{3} \mathrm{O}\right), 3.89\left(\mathrm{~s}, 3 \mathrm{H}, \mathrm{CH}_{3} \mathrm{O}\right) ;{ }^{13} \mathrm{C}-\mathrm{RMN}\left(75 \mathrm{MHz}, \mathrm{CDCl}_{3}\right) \quad \delta=149.2$, 149.0, 143.2, 130.1 (ArC), 128.3, 127.7, 125.6, 123.9, 120.1, 119.7, 111.3, 108.6 (CH), 56.0, $55.9\left(\mathrm{CH}_{3}\right)$; HRMS (m/z): Calcd for $\mathrm{C}_{14} \mathrm{H}_{14} \mathrm{O}_{2} \mathrm{~S}: 246.0715$; Found: 246.0733; Elemental Analysis calcd. for $\mathrm{C}_{14} \mathrm{H}_{14} \mathrm{O}_{2} \mathrm{~S}$ : C 68.26, H 5.73, S 13.02; Found: C 68.30, H 5.78, S 13.07.

The following compounds are known: $(E)-1,2,3$-trimethoxy-5-(4-methoxystyryl)benzene, ${ }^{27}(E)$ 1,2,3-trimethoxy-5-(4-methoxystyryl)benzene, ${ }^{28} \quad(E)$-1,2-dimethoxy-4-(4-methoxystyryl) benzene, ${ }^{29}(E)$-stilbene, ${ }^{30}(E)$-1,2-di(4-clorofenil)etileno, ${ }^{31}(E)$-1-nitro-4-styrylbenzene, ${ }^{32}(E)-1$ chloro-4-styrylbenzene, ${ }^{33}$ methyl cinnamate, ${ }^{34}(E)$-ethyl 3-(4-chlorophenyl)but-2-enoate, ${ }^{12 \mathrm{~g}}(E)$ tert-butyl 3-(4-chlorophenyl)acrylate, ${ }^{12 \mathrm{~g}}(E)$-3-(4-fluorophenyl)-3-phenylpropenonitrile, ${ }^{12 \mathrm{~g}}(E)$-3(4-fluorophenyl)-3-phenylpropenoic acid, ${ }^{12 g}(E)$-4-fluorocinnamic acid, ${ }^{35}(E)$-tert-butyl 3-(4methylphenyl)acrylate, ${ }^{36}$ (E)-tert-butyl 3-(4-acetylphenyl)acrylate, ${ }^{37}(E)$ - tert-butyl 3-(4methoxyphenyl)-2-propenoate, ${ }^{38}(E)$-cinnamonitrile, ${ }^{39}$ 3-phenyl- $N, N$-dimethyl-2-propenamide, ${ }^{40}$ dimethyl (E)-5-phenylitaconate, ${ }^{41}(E)-4$-phenyl-3-buten-2-one, ${ }^{42}(E)-4$-(4-hydroxyphenyl)but-3en-2-one, ${ }^{43} \quad(E)$-4-(4-methoxyphenyl)but-3-en-2-one, ${ }^{44} \quad(E)$-tert-butyl 3-(4chlorophenyl)acrylate, ${ }^{45}$ and $(E)$-tert-butyl 3-(4-methoxyphenyl)acrylate. ${ }^{46}$ 


\section{Acknowledgements}

This work was financially supported by the Dirección General de Investigación of the Ministerio de Educación y Ciencia of Spain (Grants CTQ2004-00808/BQU, CTQ2007-62771/BQU, and Consolider INGENIO 2010 CSD2007-00006), the Generalitat Valenciana (GV05/157), and the University of Alicante. E. A. thanks the Ministerio de Educación y Ciencia of Spain for a predoctoral fellowship.

\section{References}

1. (a) Mizoroki, T.; Mori, K.; Ozaki, A. Bull. Chem. Soc. 1971, 44, 581. (b) Heck, R. F.; Nolley, J. P. J. Org. Chem. 1972, 37, 2320.

2. For recent reviews and monographies, see: (a) Beletskaya, I. P.; Cheprakov, A. V. Chem. Rev. 2000, 100, 3009. (b) Withcombe, N.; Hii (Mimi), K. K.; Gibson, S. Tetrahedron 2001, 57, 7449. (c) de Vries, J. G. Can. J. Chem. 2001, 79, 1086. (d) Larhed, M.; Hällberg, A. In Handbook of Organopalladium Chemistry for Organic Synthesis, Negishi, E.; de Meijere, A., Eds.; John Wiley \& Sons: Chichester, 2002; pp 1133-1178. (e) Metal-Catalyzed CrossCoupling Reactions, $2^{\text {nd }}$ Edn.; Diederich, F.; de Meijere, A. Eds.; Wiley-VCH: Weinheim, 2004. (f) Transition Metals for Organic Synthesis, Building Blocks and Fine Chemicals, $2^{\text {nd }}$ Edn.; Beller, M.; Bolm, C., Eds.; Wiley-VCH: Weinheim, 2004. (g) Tsuji, J. Palladium Reagents and Catalysis, Wiley: Chichester, 2004. (h) Alonso, F.; Beletskaya, I. P.; Yus, M. Tetrahedron 2005, 61, 11711. (i) Polshettiwar, V.; Molnár, A. Tetrahedron 2007, 63, 6949.

3. For reviews, see: (a) Dupont, J.; Pfeffer; M.; Spencer, J. Eur. J. Inorg. Chem. 2001, 1917. (b) Bedford, R. B. Chem. Commun. 2003, 1787. (c) Bedford, R. B.; Cazin, C. S. J.; Holder, D. Coord. Chem. Rev. 2004, 248, 2283. (d) Beletskaya, I. P.; Cheprakov, A. V. J. Organomet. Chem. 2004, 689, 4055. (e) Dunina, V. V.; Gorunova, O. N. Russ. Chem. Rev. 2004, 73, 309. (f) Dupont, J.; Consorti, C. S.; Spencer, J. Chem. Rev. 2005, 105, 2527.

4. (a) Consorti, C. S.; Flores, F. R.; Dupont, J. J. Am. Chem. Soc. 2005, 127, 12054.

5. Reetz, M. T.; de Vries, J. G. Chem. Commun. 2004, 1559.

6. Bletskaya, I. P.; Kashin, A. N.; Karlstedt, N. B.; Mitin, A. V., Cheprakov, A. V.; Kazankov, G. M. J. Organomet. Chem. 2001, $622,89$.

7. Nowotny, M.; Hanefeld, U.; van Koningsfeld, H.; Maschmeyer, T. Chem. Commun. 2000, 1877.

8. For accounts, see: (a) Alacid, E.; Alonso, D. A.; Botella, L.; Nájera, C.; Pacheco, M. C. Chem. Rec. 2006, 6, 117. (b) Alonso, D. A.; Botella, L.; Nájera, C.; Pacheco, M. C. Synthesis 2004, 1713.

9. (a) Alonso, D. A.; Nájera, C.; Pacheco, M. C. Org. Lett. 2000, 2, 1823. (b) Alonso, D. A.; Nájera, C.; Pacheco, M. C. Adv. Synth. Catal. 2002, 344, 172.

10. Rosner, T.; Le Bars, J.; Pfaltz, A.; Blackmond, D. G. J. Am. Chem. Soc. 2001, 123, 1848. 
11. Complexes $\mathbf{1}$ and $\mathbf{2}$ are commercially available (Aldrich).

12. Mizoroki-Heck reaction: (a) Iyer, S.; Ramesh, C. Tetrahedron Lett. 2000, 41, 8981. (b) Iyer, S.; Jayanthi, A. Tetrahedron Lett. 2001, 42, 7877. (c) Iyer, S.; Kulkarni, G. M.; Ramesh, C. Tetrahedron 2004, 60, 2163. (d) Botella, L.; Nájera, C. Tetrahedron Lett. 2004, 45, 1833. (e) Botella, L.; Nájera, C. Tetrahedron 2004, 60, 5563. (f) Botella, L.; Nájera, C. Tetrahedron Lett. 2004, 45, 1833. (g) Botella, L.; Nájera, C. J. Org. Chem. 2005, 70, 4360. (h) Botella, L.; Nájera, C. Tetrahedron 2005, 61, 9688. (i) Cao, X.-P.; Barth, D.; Kuck, D. Eur. J. Org. Chem. 2005, 3482. (j) Climent, M. J.; Corma, A.; Iborra, S.; Mifsud, M. Adv. Synth. Catal. 2007, 349, 1949. (k) Alacid, E.; Nájera, C. Adv. Synth. Catal. 2007, 349, 2572. Suzuki-Miyaura reaction: (1) Botella, L.; Nájera, C. Angew. Chem. Int. Ed. 2002, 41, 179. (m) Alonso, D. A.; Nájera, C.; Pacheco, M. C. J. Org. Chem. 2002, 67, 5588. (n) Botella, L.; Nájera, C. J. Organomet. Chem. 2002, 663, 46-57. (o) Costa, A.; Nájera, C.; Sansano, J. M. J. Org. Chem. 2002, 67, 5216. (p) Baleizao, C.; Corma, A.; García, H.; Leyva, A. J. Org. Chem. 2004, 69, 439. (q) Ortiz, R.; Yus, M. Tetrahedron 2005, 61, 1699. Hiyama reaction: (r) Alacid, E.; Nájera, C. Adv. Synth. Catal. 2006, 348, 945. (s) Alacid, E.; Nájera, C. Adv. Synth. Catal. 2006, 348, 2085. Cassar-Heck-Sonogashira reaction: (t) Alonso, D. A.; Nájera, C.; Pacheco, M. C. Tetrahedron Lett. 2002, 43, 9365. (u) Alonso, D. A.; Nájera, C.; Pacheco, M. C. Adv. Synth. Catal. 2003, 345, 1146. Alkynes acylation reaction: (v) Alonso, D. A.; Nájera, C.; Pacheco, M. C. J. Org. Chem. 2004, 69, 1615.

13. Alacid, E.; Nájera, C. Synlett 2006, 2959.

14. Climent, M. J.; Corma, A.; Iborra, S.; Mifsud, M. Adv. Synth. Catal. 2007, 349, 1949.

15. See, reference $12 \mathrm{e}$.

16. See, Sinha, A. K.; Kumar, V.; Sharma, A.; Sharma. A.; Kumar, R. Tetrahedron 2007, 63, 11070, and references cited therein.

17. Petit, G. R.; Grealish, M. P.; Jung, M. K.; Hamel, E.; Pettit, R. K.; Chapuis, J.-C.; Schmidt, J. M. J. Med. Chem. 2002, 45, 2534.

18. Kim, S.; Ko, H.; Park, J. E.; Jung, S.; Lee, S. K.; Chun, Y.-J. J. Med. Chem. 2002, 45, 160.

19. Deboves, H. J. C.; Montalbetti, C. A. G. N.; Jackson, R. F. W. J. Chem. Soc., Perkin Trans. $12001,1876$.

20. Cross, G. G.; Eisnor, C. R. Gossage, R. A.; Jenkins, H. A. Tetrahedron Lett. 2006, 47, 2245.

21. (a) Larock, R. C.; Doty, M. J. J. Org. Chem. 1993, 58, 4579. (b) Larock, R. C.; Yum, E. K.; Refvik, M. D. J. Org. Chem. 1998, 63, 7652. For a review, see: Larock, R. C. J. Organomet. Chem. 1999, 576, 111.

22. See, for instance: (a) Yu, K.; Sommer, W.; Richardson, J. M.; Weck, M.; Jones, C. W. Adv. Synth. Catal. 2005, 347, 161. (b) Cassol, C. C.; Umpierre, A. P.; Machado, G.; Wolke, S. I.; Dupont, J. J. Am. Chem. Soc. 2005, 127, 3298. (c) Phan, N. T. S.; van der Sluys, M.; Jones, C. W. Adv. Synth. Catal. 2006, 348, 609.

23. Garret, C. E.; Prasad, K. Adv. Synth. Catal. 2004, 346, 889.

24. Gaikwad, A. V.; Holuigue, A.; Thathagar, M. B.; ten Elshof, J. E.; Rothenberg, G. Chem. Eur. J. 2007, 13, 6908. 
25. Xu, Y.-C.; Wulff, W. D. J. Org. Chem. 1987, 52, 3263.

26. Cheek, G. T.; Nelson, R. F. J. Org. Chem. 1978, 43, 1230.

27. Cross, G.G., Eisnor, C. R., Gossage, R. A., Jenkins, H. A. Tetrahedron Letters 2006, 47, 2245.

28. See reference 18 .

29. Cardile, V.; Lombardo, L.; Spatafora, C.; Tringali, C. Bioorg. Chem. 2005, 33, 22.

30. Zhang, Z.; Zha, Z.; Gang, C.; Pan, C.; Zhou, Y.; Wang, Z.; Zhou, M-M. J. Org. Chem. 2006, 71,4339 .

31. Dubois, J. -E.; Ruasse, M. -F. J. Org. Chem. 1973, 38, 493.

32. Miljanić, S.; Frkanec, L.; Meić, Z.; Žinić, M. Eur. J. Org. Chem. 2006, 1323.

33. Prukała, W.; Majchrzak, M.; Pietraszuk, C.; Marciniec, B. J. Mol. Catal. A: Chemical 2006, $254,58$.

34. Zhang, Z.; Wang, Z. J. Org. Chem. 2006, 71, 7485.

35. Fukuyama, T.; Arai, M.; Matsubara, H.; Ryu, I. J. Org. Chem. 2004, 69, 8105.

36. Mino, T.; Shirae, Y.; Sasai, Y.; Sakamoto, M.; Fujita, T. J. Org. Chem. 2006, 71, 6834.

37. Dawood, K. M.; Solodenko, W.; Kirschning, A. ARKIVOC 2007, (v), 104.

38. Gillespie, K. M.; Sanders, C. J.; O’Shaughnessy, P.; Westmoreland, I.; Thickitt, C. P.; Scott, P. J. Org. Chem. 2002, 67, 3450.

39. Zhang, Z.; Liebeskind, L. S. Org. Lett. 2006, 19, 4331.

40. Tsuge, O.; Sone, K.; Urano, S.; Matsuda, K. J. Org. Chem. 1982, 47, 5171.

41. Miguel del Corral, J. M.; Gordaliza, M.; Castro, M. A.; Salinero, M. A.; Dorado, J. M.; San Feliciano, A. Synthesis 2000, 154.

42. Inaba, S.; Rieke, R. D. J. Org. Chem. 1985, 50, 1373.

43. Chakraborti, A. K.; Sharma, L.; Nayak, M. K. J. Org. Chem. 2002, 67, 6406.

44. Concellón, J.M.; Rodríguez-Solla, H.; Méjica, C. Tetrahedron 2006, 62, 3292.

45. Martínez, R.; Voica, F.; Gênet, J-P.; Darses, S. Org. Lett. 2007, 9, 3213.

46. Imashiro, R.; Masahiko, S. J. Org. Chem. 2004, 69, 4216. 